\title{
Infecția cu virusul varicelo-zosterian în sarcină
}

\author{
Geta Vancea $^{1,2}$, Petre I. Calistru ${ }^{1,2}$, Emanoil Ceauşu ${ }^{1,2}$ \\ ${ }^{1}$ Spitalul Clinic de Boli Infecţioase şi Tropicale „Dr. Victor Babeş“, Bucureşti, România \\ ¿Universitatea de Medicină şi Farmacie „Carol Davila“, Bucureşti, România
}

\begin{abstract}
REZUMAT
Infecţia cu virusul varicelo-zosterian (VVZ) este o cauză importantă de morbiditate, cu răspândire la nivel global, ce determină două forme clinice distincte de boală: varicela şi herpesul zoster. Infecţia primară cu VVZ în timpul sarcinii poate avea consecinţe importante atât asupra sănătăţii materne, cât şi fetale. Datele epidemiologice arată că vaccinarea a redus semnificativ numărul infecţiilor cu VVZ atât la mame cât şi la nounăscuţi. Strategiile de vaccinare diferă în funcţie de individul la risc (mamă, nou-născut, copil), de momentul cu riscul cel mai mare de infectare (primul trimestru de sarcină, ultimul trimestru de sarcină sau postnatal) şi de durata imunităţii protectoare după vaccinare.

Cea mai frecventă complicaţie a varicelei la mamă în timpul sarcinii este pneumonia variceloasă, care se manifestă cu tuse, dispnee, febră şi tahipnee. Efectele infecţiei VVZ asupra fătului pot fi: sindromul de varicelă congenitală, prematuritate sau avort spontan, varicela neonatală. Varicela congenitală a fost descrisă pentru prima dată în 1947. Ratele de avort spontan, naşterile premature şi decesul intrauterin nu sunt mai mari la mamele cu varicelă în sarcină comparativ cu cele fără varicelă. Infecţia neonatală rezultă din transmisia VVZ de la mamă la făt în perioada perinatală.
\end{abstract}

Cuvinte cheie: varicelă, herpes zoster, sarcină, congenital, profilaxie

\section{INTRODUCERE}

Infecția cu virusul varicelo-zosterian (VVZ) determină două forme clinice distincte de boală: varicela şi herpesul zoster. Varicela, infecția primară cu VVZ, are ca rezultat o erupție veziculoasă generalizată, iar recurența infecției, herpesul zoster, determină o afecțiune localizată.

Varicela este responsabilă de 4,2 milioane de spitalizări şi 4.200 de decese anual, în întreaga lume, fiind o boală extrem de contagioasă care poate fi prevenită prin vaccinare (1). În țările în care a fost introdusă vaccinarea, incidența cazurilor, a spitalizărilor şi a deceselor a scăzut substanţial $(2,3)$.

În timpul sarcinii, infecția poate fi transmisă fătului şi, în funcție de momentul producerii infecției, poate determina varicelă congenitală, varicelă neonatală sau herpes zoster în prima copilărie. Dacă varicela apare în săptămâna 8-20 de sarcină, există riscul apariției la făt a sindromului de varicelă congenitală. Dacă mama dobândeşte varicela imediat înainte sau după naştere, copilul este expus riscului de varicelă neonatală.

Varicela maternă în timpul sarcinii este, de asemenea, asociată cu dezvoltarea herpesului zoster în copilărie (4).

Infecția primară cu VVZ în timpul sarcinii poate avea consecințe semnificative atât asupra sănătății materne, cât şi fetale. Herpesul zoster la gravidă nu este asociat cu un risc semnificativ de malformații congenitale.

Femeile gravide, fetuşii nenăscuţi şi nou-născuții reprezintă trei populații cu risc crescut care pot fi protejați împotriva infecției cu VVZ prin vaccinare, existând protocoale specifice privind imunizarea maternă (5). Strategiile de vaccinare diferă în funcție de individul la risc (mamă, nou-născut, copil), 
de momentul cu cel mai mare risc de infectare (primul trimestru de sarcină, ultimul trimestru de sarcină sau postnatal) şi de durata imunității protectoare după vaccinare (5).

Deşi frecvența cazurilor de varicelă la adulții cu vârstă peste 20 de ani este sub $2 \%$, un sfert din totalul deceselor determinate de infecția cu VVZ se înregistrează la această grupă de vârstă (6). Femeile gravide care apațin acestei grupe de vârstă sunt astfel expuse şi ele unui risc substanţial de morbiditate şi mortalitate.

\section{ETIOLOGIE}

Virusul varicelo-zosterian este un virus ADN ce aparține ordinului Herpesvirales, familia Herpesviridae, subfamilia Alphaherpesvirinae, genul Varicellovirus (7). Este un virus exclusiv uman, cu un diametru de aproximativ $175 \mathrm{~nm}(8,9)$.

$\mathrm{Cu}$ un genom linear de ADN dublu catenar de aproximativ 125.000 de perechi de baze şi 71 de gene ORFs, este cel mai mic dintre virusurile herpetice umane, fiind primul care a fost complet secvențiat (10). Prezintă aproximativ 40 de gene similare altor virusuri herpetice umane (11).

Genomul viral este localizat într-o capsidă icosaedrică (162 capsomere), care este înconjurată de un strat proteic şi încapsulată într-o anvelopă de poliamine, lipide şi glicoproteine. Glicoproteinele din anvelopă facilitează pătrunderea virusului în celule (12). Există un singur serotip de VVZ cu cel puțin 9 clade, care variază în funcție de aria geografică. Cele mai multe virusuri din emisfera vestică aparțin cladelor 1 şi 3; clada 2 este întâlnită frecvent în Asia (13).

\section{EPIDEMIOLOGIE}

Varicela este prezentă în întreaga lume. Are un model sezonier distinct în zonele temperate, unde cea mai mare incidență este în timpul iernii şi primăvara (14). Înainte de introducerea vaccinării, incidența anuală a varicelei în multe țări europene a fost corespunzătoare cohortei de nou-născuți (15).

Epidemiologia este diferită în țările tropicale, unde nu există o sezonalitate evidentă. Infecția este mai rar dobândită în copilărie comparativ cu țările temperate, astfel, doar 25-85\% dintre subiecți prezintă infecția primară înainte de vârsta de 15 ani (14). Diferite ipoteze au încercat să explice această diferență: inactivarea virală datorată temperaturilor ambientale ridicate, rasa, interferența altor virusuri şi lipsa de expunere datorită condițiilor de trai din zonele tropicale, unde VVZ nu circulă foarte mult. (14)

Epidemiologia infecției s-a schimbat în țările industrializate din cauza creşterii imigrației şi/sau creşterii gradului de acoperire prin vaccinare; incidența infecției a scăzut cu 57-95\% la toate grupele de vârstă acolo unde vaccinarea este larg răspândită $(14,15)$.

Incidența medie a varicelei în timpul sarcinii este estimată la 0,7-3 cazuri la 1.000 sarcini $(16,17)$.

Datele epidemiologice arată că vaccinarea a redus numărul infecțiilor cu VVZ atât la mame, cât şi la făt. Astfel, în Australia, între 2006 şi 2009, incidența varicelei congenitale a ajuns la 0,19 la 100.000 de nou-născuți vii/an, iar incidența infecțiilor neonatale a fost de doar 2 la 100.000 de nounăscuți vii (18). S-a înregistrat o scădere cu 85\% a cazurilor de varicelă la nou-născuți în perioada postvaccinală, comparativ cu cea prevaccinală.

\section{Sursa de infecție}

Omul este singurul rezervor cunoscut de VVZ, sursa de infecție fiind reprezentată de bolnavul cu varicelă sau herpes zoster. Nu există purtători sănătoşi de VVZ.

\section{Calea de transmitere}

Calea de transmitere a varicelei este directă, de la persoană la persoană, prin secreții respiratorii infectate ce provin din mucoasa nazo-faringiană (aerosoli, picături Flugge) şi pătrund prin mucoasa conjunctivală, nazală şi orală. Transmiterea se realizează şi prin contactul direct cu conţinutul cu virus al veziculelor cutanate sau cu obiecte proaspăt contaminate cu acest lichid vezicular. Persoanele susceptibile pot dobândi infecția şi de la pacienții cu zoster, dar ratele de transmisie sunt considerabil mai scăzute şi necesită contact direct cu leziunile cutanate.

Transmiterea verticală, de la mamă la copil, este rară. Aceasta se poate realiza în uter, perinatal sau postnatal. Infecția intrauterină sau perinatală a fătului este facilitată prin transport transplacentar, în timp ce varicela postnatală este transmisă prin picături respiratorii sau contact direct $\mathrm{cu}$ un pacient $\mathrm{cu}$ varicelă (19). 
Transmiterea virusului varicelo-zoster la făt în timpul episodului de herpes zoster este rară $(4,20)$. Ratele scăzute de transmitere pot fi asociate cu preexistența anticorpilor VVZ materni şi cu nivelurile mai scăzute de viremie care însoțesc reactivarea infecției cu VVZ.

Receptivitatea este totală la persoanele seronegative pentru VVZ. Varicela este extrem de transmisibilă, cu rate secundare de atac la persoanele susceptibile de $90 \%$ în epoca prevaccinării (6).

\section{Contagiozitatea}

Pacienții sunt infecțioşi începând cu 1-2 zile înainte de apariția erupției de varicelă până când leziunile sunt în cruste.

\section{PATOGENIE}

După transmiterea la o gazdă susceptibilă, VVZ proliferează în orofaringe, infectează celulele T şi produce o primă viremie; celulele T transportă virusul în piele şi în alte organe. Infecția este iniţial controlată de imunitatea înnăscută, care întârzie multiplicarea virală la nivel epidermic şi astfel permite imunității adaptative să se dezvolte (21).

Replicarea virusului la nivel epidermic cu surmontarea răspunsurilor antivirale locale duce la apariția leziunilor cutanate caracteristice ale varicelei. Perioada de incubație variază de la 10 la 21 de zile.

Replicarea virală este controlată atât de răspunsul imun înnăscut, cât şi de cel adaptativ, cu apărarea mediată inițial prin celulele NK şi interferoni de tip 1 (11). Celulele T specifice VVZ, care sunt esențiale pentru a opri faza viremică şi pentru a permite vindecarea varicelei, devin detectabile la 1-3 zile după apariția erupției cutanate. Aceste celule T specifice VVZ ţintesc antigene care includ glicoproteina $\mathrm{gE}$ a VVZ, proteina 62 şi alte proteine virale (21). Severitatea infecției este corelată invers proporțional $\mathrm{cu}$ rapiditatea proliferării celulelor $\mathrm{T}$ şi cu intensitatea acestui răspuns.

Persoanele cu deficit de celule T, cum sunt pacienții cu afecțiuni maligne hematologice, în tratament chimioterapic sau cu HIV, prezintă de regulă varicela severă (22). Imunitatea celulară T specifică VVZ este inițiată printr-un răspuns al celulelor T helper tip 1 (Th1), care produc citokine caracteristice cum ar fi interleukina 2 (IL-2), IL-12, factorul de necroză tumorală (TNF) TNF-a şi IFN-gama.
Anticorpii IgM, IgA şi IgG faţă de proteinele VVZ sunt detectabili în primele 3 zile de la apariția erupției cutanate, dar producția timpurie de anticorpi nu este asociată cu reducerea severității clinice a bolii (21). După vindecarea infecției iniţiale, VVZ rămâne latent în neuronii ganglionilor nervilor cranieni, ai rădăcinilor spinale dorsale senzitive, ai ganglionilor enterici şi autonomi, unde persistă pe tot parcursul vieții. În timpul latenței, ADN-ul VVZ este circular, nonreplicativ, cu un model foarte restrâns de exprimare a genelor virale (21). Nu se cunoaşte mecanismul prin care VVZ este transferat de la limfocitele infectate la neuroni şi nici mecanismul prin care neuronii rămân latent infectaţi (14).

Dovezi recente sugerează că latența atât a virusului VVZ, cât şi a virusului herpes simplex de tip 1 este reglată epigenetic (21).

Celulele T cu memorie specifică VVZ, cu un fenotip mixt central şi efector, sunt importante pentru menținerea latenței VVZ, imunitatea fiind stimulată periodic prin reactivarea endogenă (subclinică) şi reexpunerea exogenă la VVZ (22).

Virusul latent îşi păstrează capacitatea de a relua replicarea şi de a provoca boli clinice recurente. Creşterea reactivării VVZ odată cu vârsta este în mare parte atribuită scăderii celulelor T şi mai puţin imunității umorale (21). Este neclar însă dacă acest efect este datorat reducerii cantităţii sau modificării calității celulelor T circulante.

Ca şi în cazul varicelei, răspunsul imunității mediate de celulele $\mathrm{T}$ specifice în herpes zoster este invers corelat cu severitatea bolii şi cu riscul unor consecințe grave, cum ar fi nevralgia post-zosteriană (22).

Infecția primară cu VVZ determină, în general, imunitate pe toată durata vieții; rapoartele cazurilor de reinfectare sunt rare.

\section{Infecția maternă}

Infecția primară la mamă determină replicarea virală în amigdale şi ganglionii limfatici regionali şi, posibil, şi în țesutul ductal al glandelor salivare, cu durată de 4-6 zile, cu o primă viremie ce duce la răspândirea în alte organe interne, unde continuă replicarea. Ulterior, VVZ este din nou eliberat în sânge (viremia secundară) şi invadează țesutul cutanat rezultând exantemul în aproximativ 14 până la 21 de zile. 
Perioada de incubație la mamă se caracterizează astfel prin două faze ale viremiei, între ziua a 4-a şi a 6-a şi, respectiv, între a 10-a şi a 14-a zi după expunere. A doua viremie pare mai importantă şi riscul de trecere transplacentară a virusului este mai mare.

Anticorpii anti-VVZ apar la 10-20 de zile după infecție şi sunt transmişi la făt, asigurându-i o imunitate pasivă. VVZ are o afinitate neurotropică importantă, astfel încât efectele sale asupra sistemului nervos pot explica o mare parte a malformațiilor.

Majoritatea cazurilor raportate se referă la o infecție care s-a produs înainte de 20 de săptămâni de gestație; dincolo de acest termen apariția varicelei congenitale este excepțională. După 20 de săptămâni de sarcină, mecanismul este diferit şi determină tabloul de varicelă neonatală (16).

\section{Infecția intrauterină}

Mecanismul infecţiei VVZ în uter este incomplet cunoscut. Este acceptat faptul că viremia maternă conduce la infecția placentei şi ulterior la infecție fetală. ADN VVZ a fost detectat în mai multe organe fetale, iar examinarea histologică a placentei a evidenţiat granuloame şi inflamație acută (23). Locurile replicării VVZ la făt nu sunt cunoscute. S-a sugerat că fătul dezvoltă varicelă in utero urmată de vindecare, cu infecția ulterioară a ganglionilor rădăcinilor dorsale. Acest fapt are ca rezultat distrugerea celulelor țesutului nervos, cu apariția modificărilor membrelor fătului observate în varicela congenitală.

\section{MANIFESTĂRI CLINICE ÎN INFECTJIA MATERNĂ}

\section{Varicela necomplicată}

Formele necomplicate de varicelă prezintă rashul caracteristic, pruriginos, generalizat, apărut în valuri succesive, cu un prodrom de febră, astenie, mialgii. Leziunile cutanate evoluează caracteristic de la maculă, papulă, veziculă cu conținut clar, apoi tulbure, cu formarea unor cruste care lasă după desprindere, temporar, o zonă hipopigmentată.

\section{Varicela complicată}

Complicațiile cele mai frecvente ale varicelei apar mai ales la adult şi sunt reprezentate de menin- gită, encefalită, ataxie cerebeloasă, pneumonie, miocardită, glomerulonefrită, deces.

Cea mai frecventă complicaţie a varicelei în timpul sarcinii este pneumonia variceloasă, care se manifestă cu tuse, dispnee, febră şi tahipnee. Pneumonia se dezvoltă, de regulă, în prima săptămână de erupție cutanată. Evoluția clinică este imprevizibilă, cu progresie rapidă cu hipoxie şi insuficiență respiratorie (24). Radiologic, se evidenţiază infiltrație difuză, miliară sau nodulară, cu distribuție peribronşică, afectând ambii plămâni. Pneumonia variceloasă complică 10-20\% dintre cazurile de varicelă din timpul sarcinii.

Femeile gravide cu pneumonie VVZ trebuie spitalizate pentru monitorizarea şi inițierea terapiei antivirale; până la 40\% dintre aceste pneumonii necesită ventilație mecanică (25). Riscul pentru pneumonie creşte odată cu vârsta gestațională din cauza imunosupresiei materne şi a unui factor pur mecanic, ascensionarea diafragmei ca urmare a creşterii uterului gravid (25).

Mortalitatea în cazurile severe care necesită ventilație mecanică a scăzut de la $45 \%$ la $3-14 \%$ în prezent (25).

\section{Diagnostic}

Diagnosticul varicelei la gravidă este, în mod obişnuit, un diagnostic clinic. Dacă există îndoieli cu privire la diagnosticul clinic, infecția cu VVZ poate fi confirmată rapid prin detectarea ADN-ului viral, prin PCR din produsul obținut prin raclajul pielii de la baza veziculei sau prin detectarea antigenului VVZ prin imunofluorescență. VVZ poate fi cultivat din lichidul vezicular, dar virusul replică lent, astfel încât cultura este mult mai puțin utilizată decât tehnicile de detecție directă.

Testarea serologică nu este necesară pentru diagnosticul varicelei materne.

Efectele infecției VVZ asupra fătului pot fi: sindromul de varicelă congenitală, prematuritate sau avort spontan, varicelă neonatală.

\section{VARICELA CONGENITALĂ}

Varicela congenitală a fost descrisă pentru prima dată în 1947. Este asociată cu o rată a mortalităţii de 30\% în primele luni de viață şi cu un risc de 15\% de a dezvolta herpes zoster între a 2-a şi a 41-a lună de viață. $\mathrm{Cu}$ toate acestea, în ciuda prognosticului 
nefavorabil, există şi supraviețuire pe termen lung (25).

\section{Incidența varicelei congenitale în funcție de vârsta de gestație}

Varicela în primele două trimestre de sarcină are ca rezultat infecția intrauterină până la $25 \%$ dintre cazuri, dar anomaliile congenitale apar doar la 12\% dintre feții infectați (25). Varicela maternă survenită în primele 20 de săptămâni de sarcină a fost asociată cu o incidență a varicelei congenitale de $0,91 \%$ (26). Au fost raportate rar cazuri de varicelă congenitală după varicela maternă apărută între 20 şi 28 săptămâni de gestație, dar nu au fost înregistrate astfel de cazuri după săptămâna 28 de gestație (26).

Deşi caracteristicile clinice ale varicelei congenitale sunt multi-sistem, unele țesuturi şi organe sunt afectate selectiv $(27,28)$ :

- cicatrici cutanate cu pattern dermatomeric

- hipoplazia membrelor

- anomalii neurologice (retard mental, microcefalie, hidrocefalie, convulsii, sindromul Horner)

- anomalii oculare (atrofie optică, cataractă, corioretinită, microftalmie, nistagmus)

- anomalii ale membrelor (hipoplazie, atrofie, pareză)

- anomalii gastro-intestinale (reflux gastroesofagian, atrezie sau stenoză intestinală)

- greutate mică la naştere

Dacă leziunile cutanate apar în aproximativ $70 \%$ dintre cazuri, hipoplazia membrelor a fost înregistrată în 46-72\% dintre cazuri. Anomaliile neurologice înregistrează o frecvență de până la $62 \%$ dintre cazuri, iar tulburările oculare s-au identificat până la 52\% dintre cazuri (25). Hipoplazia musculară, întârzierea dezvoltării, anomalii ale tractului gastrointestinal, ale celui genito-urinar şi ale sistemului cardiovascular apar în 7-24\% dintre cazuri. Hipoplazia osoasă şi leziunile cutanate au localizare dermatomerică (17).

\section{Mecanismul de producere a varicelei congenitale}

Apariția acestei afecțiuni se datorează, cel mai probabil, reactivării VVZ in utero, situație asemănătoare producerii herpesului zoster. Perioada scurtă de latență dintre infecția primară şi reactivare poate fi determinată de imaturitatea imunității fetale mediată celular (31). Dovezile pentru reactivare provin din aspectul dermatomeric al leziunilor cutanate, similar cu herpesul zoster, din modificările segmentare ale dezvoltării sistemului musculoscheletal şi disfuncția sistemelor nervoase somatice şi autonome (24).

\section{Diagnosticul varicelei congenitale}

\section{Diagnosticul prenatal}

După infecția maternă, riscul de varicelă congenitală poate fi estimat prin testarea sângelui fetal sau a lichidului amniotic prin PCR pentru ADNVVZ, împreună cu ultrasonografia pentru detectarea anomaliilor fetale (27).

Testarea PCR pentru ADN-VVZ se realizează în săptămânile 17-21 de gestație. O evaluare detaliată anatomică ultrasonografică se va realiza nu mai devreme de cinci săptămâni după infectarea maternă, pentru a evidenţia instalarea anomaliilor (17).

Rezultatele normale ale ultrasonografiei şi ale testelor de laborator sugerează un risc scăzut de varicelă congenitală. $\mathrm{O}$ ecografie normală cu $\mathrm{ADN}$ VVZ detectabil sugerează un risc potențial şi este indicată o repetare a ultrasonografiei la 22-24 de săptămâni. Dacă ecografia repetată este normală, riscul de varicelă congenitală este scăzut. Dacă ultrasonografia prezintă dovezi ale varicelei congenitale, gravida trebuie înştiințată despre boala probabilă a fătului (17).

Testarea serologică a fătului are o utilitate limitată din cauza sensibilității şi specificității scăzute.

\section{Diagnosticul postnatal}

Diagnosticul de varicelă congenitală necesită următoarele criterii (25):

- istoric de infecție maternă cu varicelă în primul sau al doilea trimestru de sarcină

- prezența anomaliilor fetale compatibile cu sindromul de varicelă congenitală

- dovada infecției intrauterine cu VVZ

Dovezile infecției intrauterine pot include oricare dintre următoarele situații:

- detectarea ADN-VVZ la nou-născut;

- prezența anticorpilor IgM specifici VVZ în sângele din cordonul ombilical;

- persistența IgG specifici VVZ după vârsta de şapte luni;

- apariția herpesului zoster în primul an de viață. 
Diagnosticul varicelei congenitale poate fi confirmat prin prezența varicelei materne în timpul sarcinii, împreună cu leziunile cutanate cu distribuție dermatomerică, cu sau fără prezența semnelor neurologice, a defectelor oculare, a malformațiilor membrelor şi a convulsiilor neonatale. Dovezi retrospective ale seroconversiei IgG-VVZ materne în timpul sarcinii pot fi utile.

Aproape $20 \%$ dintre sugarii cu infecție intrauterină cu VVZ dezvoltă herpes zoster neonatal sau infantil, care de obicei este necomplicat $(25,29)$.

Detectarea serologică fetală a IgM specifice este utilă în confirmarea infecției intrauterine, dar serologia are o sensibilitate scăzută.

\section{Herpesul zoster matern și varicela congenitală}

Particularitatea infecției VVZ de a rămâne latentă în ganglionii spinali senzitivi, coroborată cu inervația uterină ce este asigurată de nervii spinali T10-L4, teoretic ar putea determina infecția intrauterină cu acest virus. Nu au fost raportate însă cazuri de varicelă congenitală după apariția unui herpes în primele două trimestre de sarcină şi nu s-au evidențiat date clinice sau serologice ale infecției cu VVZ la sugarii ale căror mame au dezvoltat herpes zoster perinatal. (25)

Nou-născuții cu varicelă congenitală nu au o boală activă, ci doar sechele.

\section{PREMATURITATEA ŞI AVORTUL SPONTAN}

Varicela nu este asociată cu avortul spontan din primul trimestru (25). Ratele de avort spontan, naşterile premature şi decesul intrauterin nu sunt mai mari la mamele cu varicelă în sarcină comparativ cu cele fără varicelă.

\section{VARICELA NEONATALĂ}

Infecția neonatală rezultă din transmisia VVZ de la mamă la făt în perioada perinatală.

Varicela neonatală poate să apară prin transmitere transplacentară, infecție ascendentă sau prin tractul respirator neonatal. Varicela neonatală apărută în primele 10-12 zile de viață este cauzată de transmiterea intrauterină, în timp ce după acest interval este datorată infecției postnatale a nou-născutului.

Atunci când varicela maternă are loc cu 1-4 săptămâni înainte de naştere, până la 50\% dintre nou- născuți vor fi infectați, iar $23 \%$ dintre aceştia vor dezvolta varicelă clinic.

Tabloul clinic al varicelei neonatale este variabil, de la forme medii de boală până la infecție diseminată severă. Nou-născuții din mame cu varicelă apărută cu cinci zile înainte şi două zile după naştere prezintă cel mai mare risc pentru boală severă şi evoluție nefavorabilă. Nou-născutul va prezenta o infecție diseminată cu erupție cutanată hemoragică, afectare pulmonară, hepatică, meningeală, cu prognostic sever (16).

Risc crescut de boală severă prezintă şi nou-născuții sub 28 de săptămâni de gestație sau cu greutate sub $1.000 \mathrm{~g}$ care nu beneficiază de transferul activ de anticorpi $\operatorname{IgG}$ materni ce se face în ultimul trimestru de sarcină, iar răspunsul imun mediat celular al copilului nu este suficient pentru a preveni răspândirea hematogenă a VVZ (16).

În perioada anterioară terapiei intensive neonatale, a utilizării imunoglobulinelor şi antiviralelor, rata mortalitătii în varicela neonatală era de $31 \%$, dar a scăzut astăzi până la 7\%.

Diagnosticul varicelei neonatale este în esență clinic, pe prezența erupției -generalizată, veziculoasă, polimorfă - la un nou-născut din mamă expusă la infecție cu VVZ sau cu simptome clinice de varicelă în perioada perinatală.

În cazurile incerte, diagnosticul este confirmat prin PCR, test cu specificitate şi sensibilitate înaltă ce detectează VVZ din lichidul vezicular, raclajul veziculei, cruste, biopsie tisulară, LCR. Acesta permite şi diferenţierea între tulpinile sălbatice şi cele din vaccin.

Testele serologice sunt utile în diagnostic, dar necesită ser acut şi din convalescență.

În infecția neonatală, aceste seruri au un titru IgG VVZ crescut, spre deosebire de nou-născuții neinfectaţi, care au titruri scăzute de anticorpi prin transfer pasiv de la mamă. Anticorpii IgM reflectă o infecție recentă, dar pot da reacții încrucişate cu virusul herpes simplex.

\section{MANAGEMENTUL INFECTSIEI MATERNE}

\section{Tratamentul varicelei la gravidă}

Varicela se tratează cu aciclovir oral (800 mg de cinci ori/zi, 7 zile) pentru toate femeile gravide cu boală necomplicată. Inițierea tratamentului în primele 24 de ore de la debutul bolii este asociată cu o vindecare mai rapidă a leziunilor cutanate şi cu scurtarea duratei febrei (30). 
Pneumonia variceloasă din timpul sarcinii este o urgenţă medicală şi necesită tratament cu aciclovir intravenos (10 mg/kg la fiecare opt ore). Raportul risc-beneficiu al tratamentului varicelei materne cu aciclovir depăşeşte orice preocupare teoretică privind toxicitatea fetală; niciun model specific de malformații congenitale nu a fost atribuit aciclovirului administrat în sarcină (31). Deşi aciclovirul traversează placenta, nu s-a demonstrat că acest agent antiviral scade riscul de sindrom congenital de varicelă (32).

Tratamentul herpesului zoster în timpul sarcinii este similar cu cel al adultelor care nu sunt însărcinate $(800 \mathrm{mg}$ de 5 ori/zi). Nu există dovezi că gravidele cu herpes zoster au un risc mai mare de complicații şi se recomandă tratarea doar a celor cu mai mult de 50 de leziuni cutanate şi cu nevrită acută (33).

\section{TRATAMENTUL INFECTJIEI LA NOU-NĂSCUT}

Nou-născuții cu varicelă severă, cu pneumonie, encefalită, hepatită sau trombocitopenie sunt tratați $\mathrm{cu}$ aciclovir intravenos, $30 \mathrm{mg} / \mathrm{kg} / \mathrm{zi}$, divizat în 3 prize, timp de 10 zile $(34,35)$. Aciclovirul nu este teratogen, traversează bariera placentară, dar concentrațiile serice fetale ajung doar la $15-20 \%$ din concentratiiile materne. Tratamentul varicelei neonatale a eliminat mortalitatea şi a redus semnificativ sechelele. Acest tratament trebuie inițiat cât mai rapid de la debut întrucât replicarea virală se opreşte după 72 de ore de la apariția erupției.

$\mathrm{Nu}$ se va utiliza aspirină pentru combaterea febrei pentru a evita riscul de producere al sindromului Reye.

\section{Alăptarea}

Excreția virusului varicelo-zosterian în laptele matern a fost demonstrată prin detecția ADN VZV la acest nivel (36). Alăptarea este benefică la nounăscuții expuşi sau infectați cu varicelă, deoarece anticorpii din laptele matern pot fi protectori. Alăptarea este recomandată indiferent de starea imunologică a mamei (16).

\section{PROFILAXIE}

\section{Profilaxia preexpunere}

Profilaxia primară a varicelei se realizează prin vaccinare. Vaccinul (vOKA) a fost dezvoltat în
Japonia în 1974 pentru a scădea complicațiile fatale ale varicelei la copiii imunodeprimați (10). Există în prezent 3 formule comerciale de vaccin pentru prevenția varicelei şi unul pentru prevenția zosterului.

Vaccinarea cu vaccin viu atenuat (Varilrix, Varivax) este indicată femeilor de vârstă fertilă şi fără antecedente de varicelă clinic. Schema de vaccinare se bazează pe administrarea a două doze la intervale de 4 până la 8 săptămâni sau între 6 şi 10 săptămâni, în funcție de vaccinul utilizat. Se recomandă contracepția în prima lună după vaccinare.

Vaccinarea este contraindicată la gravide din cauza riscului teoretic de transmitere verticală a virusului vaccinal. Vaccinarea este posibilă postpartum, inclusiv în timpul alăptării. S-a demonstrat că virusul vaccinal nu trece în laptele matern (17). Vaccinarea post-expunere administrată în primele 3-5 zile a redus cu $90 \%$ incidența varicelei la subiecții expuşi.

\section{Profilaxia postexpunere}

Prevenirea se adresează unor gazde susceptibile care nu au antecedente de infecție sau dovezi serologice de expunere prealabilă. Evaluarea susceptibilității se realizează anamnestic şi prin determinări serologice inainte de imunoprofilaxie.

Imunizarea pasivă a nou-născutului poate modifica evoluția clinică a varicelei neonatale, dar nu previne boala şi, deşi scăzut, riscul de deces nu este eliminat (38). De aceea, tratamentul $\mathrm{cu}$ aciclovir trebuie administrat prompt la o doză de $10 \mathrm{mg} / \mathrm{kg}$ la fiecare 8 ore, intravenos, timp de 7 zile în caz de suspiciune de varicelă neonatală.

Pentru a reduce mortalitatea în varicela neonatală, data naşterii poate fi amânată, permițând anticorpilor materni să treacă prin bariera placentară (23). Nu este indicată nicio terapie pentru varicelă neonatală dacă debutul erupției materne este cu mai mult de 7 zile înainte de naştere.

Imunoprofilaxia postexpunere pentru prevenirea varicelei materne se realizează prin imunizare pasivă cu imunoglobuline specifice variceloase intramuscular. Doza recomandată este de 125 u/10 kg corp până la un maxim de 625 u. În absența acestor imunoglobuline specifice, se pot utiliza imunoglobuline intravenoase, în doză de $400 \mathrm{mg} / \mathrm{kg}$ corp.

Imunizarea pasivă poate reduce viremia şi scade riscul transmiterii de la mamă la copil. 
Managementul expunerii nou-născutului la varicelă presupune atât profilaxie postexpunere, cât şi izolare. Măsurile specifice depind de momentul expunerii, statusul serologic al mamei şi vârsta gestațională. Imunoglobulinele specifice varicelozosteriene sunt imunoglobuline umane purificate obținute din plasmă cu nivel crescut de anticorpi antivaricelă.

Se recomandă imunoprofilaxia după expunerea la VVZ (varicelă sau herpes zoster) pentru pacienții care prezintă risc crescut de complicații severe şi care nu pot primi vaccin $\operatorname{VVZ}(26,38,39)$ :

- nou-născuții din mamă cu varicelă cu cinci zile înainte şi două zile după naştere

- prematuri născuți la peste 28 săptămâni de gestaţie, care sunt expuşi în timpul spitalizării şi ale căror mame nu au imunitate

- prematuri născuți sub 28 săptămâni de gestație sau care cântăresc sub $1.000 \mathrm{~g}$ la naştere şi au fost expuşi în timpul spitalizării, indiferent de dovezile de imunitate ale mamei la varicelă
- femeile gravide care nu dispun de imunitate la VVZ

Imunizarea pasivă după expunere la varicelă se poate realiza până la 10 zile.

Doza recomandată este 125 unități, intramuscular, pentru nou-născuții cu greutate peste $2,1 \mathrm{~kg}$ şi 62,5 unităţi pentru cei sub $2 \mathrm{~kg}$. Dacă nu sunt disponibile imunoglobuline specifice, se pot administra imunoglobuline intravenoase sau se face profilaxie cu aciclovir.

Izolarea mamei şi a copilului depinde de existența bolii active şi de momentul expunerii. Astfel, se izolează mama cu varicelă, iar nou-născutul va fi izolat de mamă până când aceasta nu mai este contagioasă. Orice nou-născut care prezintă varicelă în maternitate va fi izolat.

Dacă mama prezintă varicelă cu 21 de zile anterior naşterii, nu va mai fi izolată, dar nou-născutul va fi izolat de alți copii. Mama sero-negativă expusă la varicelă cu 6-21 de zile înaintea naşterii va fi izolată, întrucât poate dezvolta varicelă în timpul spitalizării. 